\title{
Contemporary stress field in the area of the 2016 Amatrice seismic sequence (central Italy)
}

\author{
Maria Teresa Mariucci, Paola Montone \\ Istituto Nazionale di Geofisica e Vulcanologia, Roma1 \\ mariateresa.mariucci@ingv.it, paola.montone@ingv.it
}

\begin{abstract}
We update the last present-day stress map for Italy relatively to the area of 2016 Amatrice seismic sequence (central Italy) taking into account a large number of earthquakes occurred from August $24^{\text {th }}$ to October $3^{r d}$, 2016. In particular in this paper, we discuss the new stress data from crustal earthquake focal mechanisms selecting those with Magnitude $\geq 4.0$; at the same time, we revise the borehole data, analyze the stratigraphic profiles and the relative sonic logs in 4 deep wells located close to the Amatrice sequence along the Apennine belt and toward east along the Adriatic foredeep. From these data we consider the Pwave velocity trend with depth and estimate rock density following an empirical relationship. Then we calculate the overburden stress magnitude for each well. The new present-day stress indicators confirm the presence of prevalent normal faulting regime and better define the local stress field in the area, highlighting a slight rotation from NE-SW to ENE-WSW of extension. The analysis evidences that the lithostatic gradient gradually changes from $\sim 26 \mathrm{MPa} / \mathrm{km}$ in the belt to less than $23 \mathrm{MPa} / \mathrm{km}$ along the Adriatic foredeep. Finally, at a depth of $5 \mathrm{~km}$ we estimate the vertical stress magnitude varying from 130 MPa to 114 moving from the Apennine belt to the Adriatic foredeep. Although the wells are very close each other they show different $P$ wave velocities from the belt to the foredeep with values $\sim 7 \mathrm{~km} / \mathrm{s}$ and $\sim 4$ $\mathrm{km} / \mathrm{s}$ at $5 \mathrm{~km}$ depth, respectively.
\end{abstract}

\section{INTRODUCTION}

$\mathrm{T}$ his paper combines present-day stress data from 2016 Amatrice seismic sequence (until October $3^{\text {rd }}, 2016$ ) and some information retrieved from the analysis of some deep wells in two different geologic context: the Apennine belt, where the earthquakes occurred, and the contiguous eastward Apennine foredeep.
Along the entire central Apennine belt (Fig. 1) the main active process is the $\sim \mathrm{NE}-\mathrm{SW}$ extension, well defined by several normal faulting focal plane solutions and fault data. NE-SW compression is limited to the external areas, along the northern Apennine front (from the Po Plain up to $\sim 42.5^{\circ}$ latitude) and also toward the central Adriatic Sea, with a localized well-depicted N-S compression [Montone and Mariucci 2016]. This extensional-compressional pairing is nowadays 
well defined and recognizable through the distribution of earthquake focal mechanisms and other present-day stress data, mainly breakouts [Frepoli et al., 1997; Lavecchia et al., 2004; Montone and Mariucci, 2016].

In this paper we consider 4 deep wells, located in the 2016 Amatrice area and along the contiguous foredeep (Fig. 1). Data from all wells include information relative to the stratigraphy and physical properties deduced from down-hole logs such as resistivity, gamma ray and sonic log. In particular, the sonic log curves display P-wave travel-times versus depth, from which we estimate the rock densities of the sequence crossed by each well; then we use density to determine the vertical stress magnitude.

Very close to the Amatrice seismic sequence, two deep wells were analyzed [Mariucci et al., 2010] in order to define the minimum horizontal stress orientation (Shmin) through the breakout analysis (Fig. 2). The boreholes, Campotosto (C) and Varoni (V), about 2500 $\mathrm{m}$ and $5700 \mathrm{~m}$ deep respectively, cross the entire Umbria-Marche succession from the flysch (arenaceous-clayey unit) belonging to "Laga Fm." (Lower Messinian) to the Middle-Lower Trias Dolomites (the deepest one). The breakout zones were identified at a depth range between 1.4 and $4.6 \mathrm{~km}$ and the results show an Shmin N81 $\pm 22^{\circ}$ and N74 $\pm 10^{\circ}$ oriented for $\mathrm{V}$ and $\mathrm{C}$ wells, respectively (Fig. 2).

In northern Italy, the analysis of several deep wells [Montone and Mariucci 2015] allowed to estimate the vertical stress magnitude (Sv) by the integration of derived rock densities from the surface to the bottom of each analyzed well. In the area mentioned above, the lithostatic gradient gradually changes from a maximum of $26 \mathrm{MPa} / \mathrm{km}$ in the northern Apennine belt to a minimum of $21 \mathrm{MPa} / \mathrm{km}$ in the Po Plain and Adriatic region. Consequently, moving from the Apennine area to the Adriatic coast, values of lithostatic pressure from 130 to $105 \mathrm{MPa}$ have been estimated for instance at a depth of $5 \mathrm{~km}$. The estimated rock density in that sector of the Apennine belt ranged from 2.65 to $2.33 \mathrm{~g} / \mathrm{cm}^{3}$ (Montone and Mariucci 2015) in good agreement with the result found in central Italy (Umbria - Marche Apennines) by other authors [Federico and Pauselli 1998; Pauselli et al. 2010].

\section{Data Analysis And RESUlts}

\section{II.1 FAult Plane SOlUtions - HoRIZONTAL STRESS ORIENTATIONS}

We have updated the recent Italian presentday stress map [Montone and Mariucci, 2016] by adding the Shmin orientations inferred from the focal mechanisms of $M \geq 4$ earthquakes of the ongoing sequence, with a maximum depth of $11 \mathrm{~km}$ (Table 1). We have taken into account the available Quick Regional Centroid Moment Tensors [http://autorcmt.bo.ingv.it/quicks.html, Pondrelli et al., 2006] for homogeneity with the other focal mechanism data already published in the previous stress maps. Ten moment tensors have been added up to October $3^{\text {rd }}, 2016$. To identify the minimum horizontal stress (Shmin) azimuth and the tectonic regime we use the plunge of the $\mathrm{P}, \mathrm{T}$ and $\mathrm{B}$ axes applying the criteria of Zoback [1992]. Following the World Stress Map guidelines [Heidbach et al. 2010], all data are well constrained but they are assigned $\mathrm{C}$ quality as "single event solutions" [McKenzie, 1969; see also Montone et al. 2012 for a detailed explanation]. 


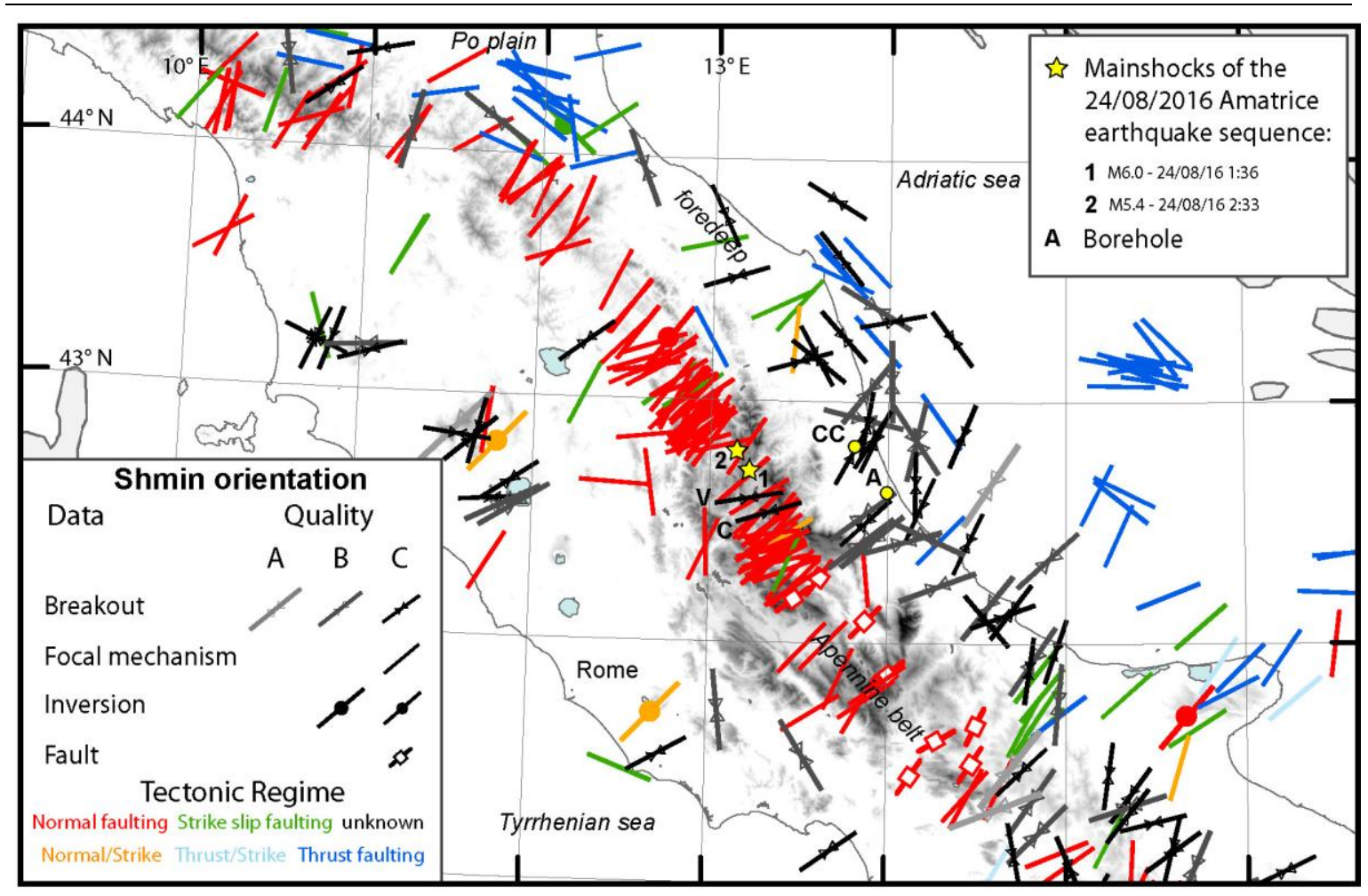

Figure 1. Present-day stress in central Italy. Minimum horizontal stress (Shmin) orientations [Montone and Mariucci, 2016) and the two mainshocks of the Amatrice seismic sequence until October $3^{\text {rd }}, 2016$ [BSI, 2016]. Normal faulting regime: Shmin=sigma 3; Strike-slip: Shmin=sigma 3; Thrust: Shmin=sigma 2. Location of the boreholes analysed in this study: A, Atri; CC, Colle Casone; C. Campotosto; V, Varoni.

The focal mechanisms are "normal-faulting" except a strike-slip mechanism in the eastern part of the seismic sequence area; the inferred Shmin orientations point out a general extension perpendicular to the Apennines with orientations from $\mathrm{N} 48^{\circ}$ to $\mathrm{N} 76^{\circ}$. Only one normal faulting event M4.4 shows a NW-SE extension. The Shmin orientations from earthquake data show a good agreement with those from borehole data although they refer to different depths. In fact as mentioned before, the reviewed borehole breakout data from the two wells available in the area (C and $\mathrm{V}$ wells) show an Shmin ENE-WSW oriented $\left(\mathrm{N} 81^{\circ}\right.$ and $\left.\mathrm{N} 74^{\circ}\right)$, only slightly different from the earthquake axes (Fig. 2). 


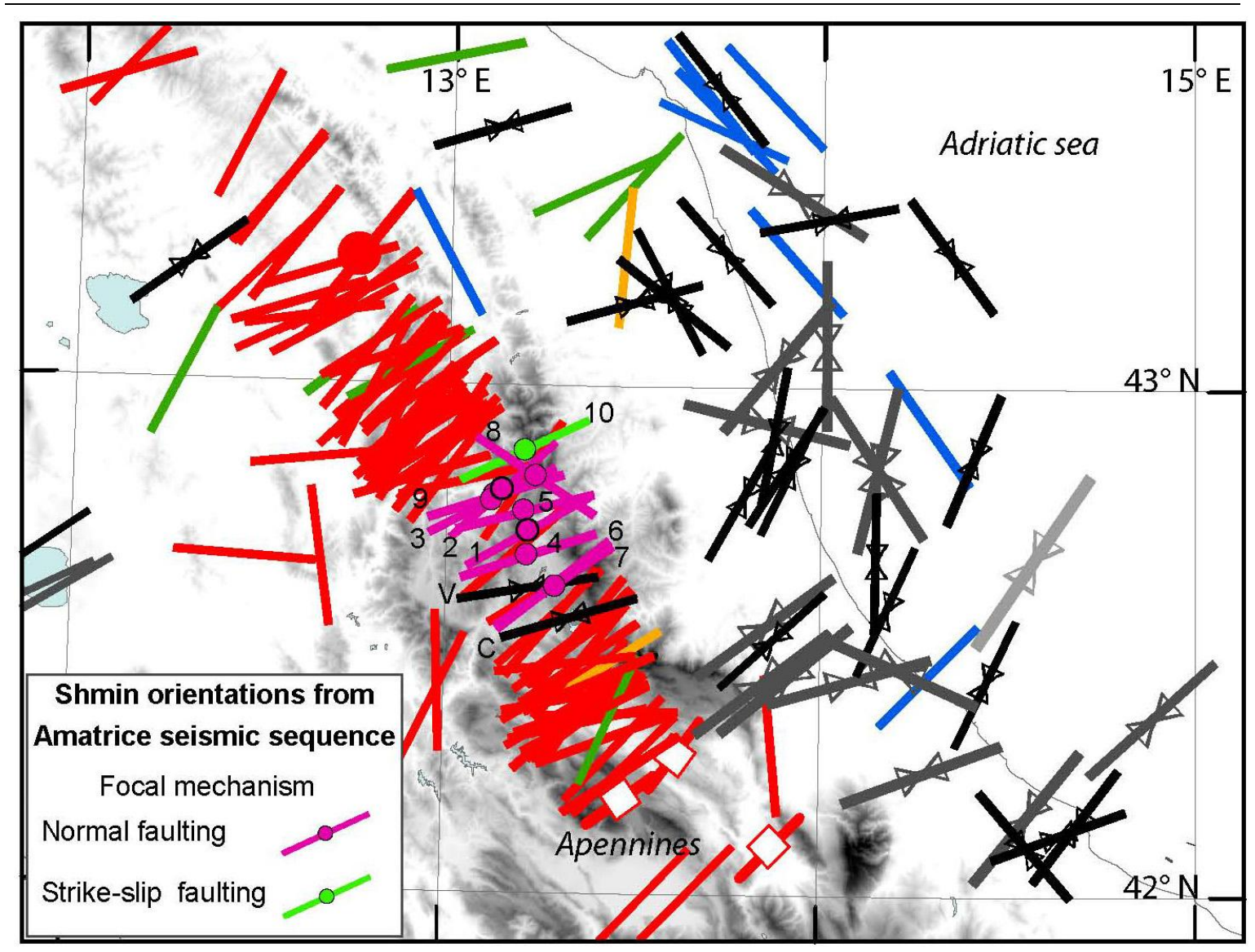

Figure 2. The 2016 Italian stress map and the new minimum horizontal stress (Shmin) orientations inferred from the available focal mechanisms of ten earthquakes with Mw $\geq 4$ [http://autorcmt.bo.ingv.it/quicks.html]. Numbers as in Table 1. Bold circles are the event $n .1$ and $n .2$ of Figure 1 and Table 1. V and C stand for Varoni and Campotosto wells. See legend in Figure 1.

\section{II.2 SONIC LOG - P-WAVE VELOCITY AND VERTICAL STRESS MAGNITUDE}

We have analysed sonic log data of the two deep boreholes within the area of the seismic sequence (V and $\mathrm{C}$ in Fig. 1) and, for comparison, two wells to an easternmost location (A and CC in Fig. 1), in the foredeep. Sonic log data are among the most important in situ measurements of rock properties and pro- vide a reliable image of in situ conditions at depth, notwithstanding their limits mainly due to the investigated rock volume and the tool working frequency.

We have inferred the P-wave velocity $(\mathrm{Vp})$ values at depth from homogeneous sonic log (slowness) intervals and, using an empirical relation for sedimentary rocks based on borehole measurements [Gardner et al., 1974], we have estimated rock density. 
Table 1. Earthquake focal mechanism data

\begin{tabular}{cccccccccc}
\hline & & Time & \multicolumn{9}{c}{$\begin{array}{c}\text { Depth } \\
\mathbf{N}\end{array}$} & Date & UTC & Mw & $(\mathbf{k m})$ & Lat N & Lon E & Shmin & Q & TR \\
\hline 1 & $24-08-2016$ & $01: 36$ & 6.0 & 8 & 42,71 & 13,22 & 61 & C & NF \\
2 & $24-08-2016$ & $02: 33$ & 5.4 & 9 & 42,79 & 13,15 & 48 & C & NF \\
3 & $24-08-2016$ & $04: 06$ & 4.3 & 8 & 42,77 & 13,12 & 63 & C & NF \\
4 & $24-08-2016$ & $17: 46$ & 4.4 & 10 & 42,66 & 13,22 & 72 & C & NF \\
5 & $25-08-2016$ & $03: 17$ & 4.5 & 10 & 42,75 & 13,21 & 76 & C & NF \\
6 & $25-08-2016$ & $12: 36$ & 4.4 & 10 & 42,60 & 13,29 & 56 & C & NF \\
7 & $26-08-2016$ & $04: 28$ & 4.8 & 11 & 42,60 & 13,29 & 52 & C & NF \\
8 & $28-08-2016$ & $15: 55$ & 4.4 & 9 & 42,82 & 13,24 & 124 & C & NF \\
9 & $03-09-2016$ & $01: 34$ & 4.3 & 11 & 42,78 & 13,13 & 73 & C & NF \\
10 & $03-09-2016$ & $10: 18$ & 4.5 & 9 & 42,87 & 13,21 & 65 & C & SS \\
\hline
\end{tabular}

Shmin: minimum horizontal stress; Q: data quality; TR: Tectonic Regime;

NF: normal faulting; SS: strike-slip faulting. See also Figure 2.

The two boreholes in the belt penetrate the whole sedimentary sequence of the region but the youngest units, whereas the two boreholes in the foredeep cross the PlioQuaternary sedimentary units only (Fig. 3). In the first $5 \mathrm{~km}$, the $\mathrm{Vp}$ clearly shows this setting with values varying from around 4 $\mathrm{km} / \mathrm{s}$ to about $7 \mathrm{~km} / \mathrm{s}$ in the Apennines; in the foredeep Vp is about $2 \mathrm{~km} / \mathrm{s}$ and reaches maximum values around $5 \mathrm{~km} / \mathrm{s}$. The values increase with depth irregularly with many inversions. It is noteworthy the abrupt $\mathrm{Vp}$ increase in well CC around $1.5 \mathrm{~km}$ and the low velocity zone in $\mathrm{V}$ well at about $5.5 \mathrm{~km}$. The magnitude of the vertical stress $(\mathrm{Sv})$ is usually estimated from the lithostatic pressure [e.g. Cornet and Rockel, 2012]. As sug- gested by the inversion of several earthquake focal mechanisms, we are confident that in the Apennine belt the three principal stresses are perpendicular to each other with one being in a vertical orientation [e.g. Frepoli and Amato, 1997], then we have evaluated the magnitude of Sv from the cumulated weight of overburden in the four selected wells.

The Sv values at depth show two different trends that reflect the different geological stratigraphic sequences (Fig. 4): in the Apennines the gradient is $\sim 26 \mathrm{MPa} / \mathrm{km}$ whereas in the Adriatic foredeep is $\sim 23 \mathrm{MPa} / \mathrm{km}$, resulting in a magnitude at $5 \mathrm{~km}$ around 130 $\mathrm{MPa}$ in the epicentral area and about 114 MPa close to the Adriatic coast. 


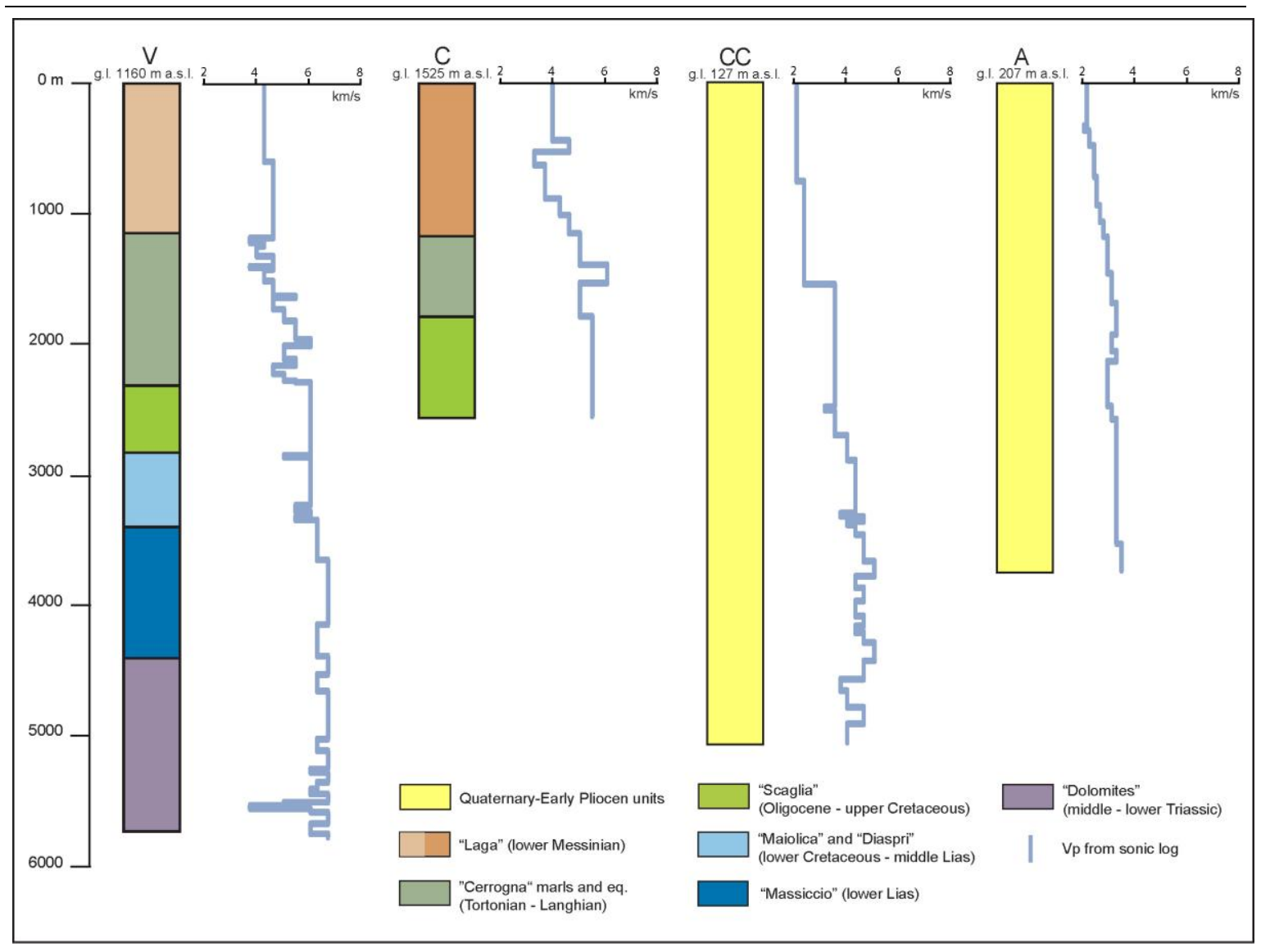

Figure 3. Stratigraphic sequence and P-wave velocity $(V p)$ at depth along $V, C, C C$, and $A$ wells (see Figure 1 for location) as inferred from sonic log.

\section{DISCUSSION AND CONCLUSIONS}

The new present-day stress data cover an area with very few information, characterized by a prevailing normal faulting regime with a NE-SW to ENE-WSW extension. The focal mechanisms of the main events (with $M \geq 4$ ) of the Amatrice seismic sequence agree with this tectonic regime, except one strike-slip mechanism, showing $\mathrm{N} 48^{\circ}$ to $\mathrm{N} 76^{\circ} \mathrm{Shmin}$ orientation

[http://autorcmt.bo.ingv.it/quicks.html]. Also the TDMT focal mechanisms of event $\mathrm{M} \geq 3.9$ of the Amatrice sequence [Scognamiglio et al., 2016] agree with this trend. The earthquake focal mechanism forecast [Roselli and Mariucci, 2016], computed before the ongoing sequence, shows a general agreement among the computed and predicted horizontal stress axes.

We have analysed in detail the sonic and stratigraphic logs of four deep wells, two located in the area of the Amatrice seismic sequence and two close to Adriatic coast. In particular, the sonic measurements provide a reliable image of in situ conditions that allow describing some physical properties of the 
first kilometers of the crust, as P-wave velocity and vertical stress magnitude.

Along the boreholes, in the first $5 \mathrm{~km}$, the $\mathrm{Vp}$ shows values varying from around $4 \mathrm{~km} / \mathrm{s}$ to about $7 \mathrm{~km} / \mathrm{s}$ in the Apennines, whereas in the foredeep $\mathrm{Vp}$ is about $2 \mathrm{~km} / \mathrm{s}$ reaching maximum values of $\sim 5 \mathrm{~km} / \mathrm{s}$. Vp increases with depth irregularly with many inversions, like the abrupt increase around $1.5 \mathrm{~km}$ in well CC and the low velocity zone at about $5.5 \mathrm{~km}$ in $\mathrm{V}$ well. The few available data do not allow obtaining a clear interpretation of the results although they could be related to different lithologies, or a different fluid content or highly fractured zones. In CC well the estimated velocity change correspond to different lithologies within the Early Pliocene succession. The low velocity interval, about $50 \mathrm{~m}$ thick, in $\mathrm{V}$ borehole is very reliable but not clearly associated to the lithologies: it occurs at the base of the dolomite interval, a highly fractured zone, then possibly characterized by a different fluid content. The Pwave velocity variations with depth in the shallow crust are often neglected by $1 \mathrm{D}$ velocity models where a unique $\mathrm{Vp}$ value is assigned to the layer down to about $5 \mathrm{~km}$ (e.g. BSI, 2016)

Concerning the estimated lithostatic gradient, we have found $26 \mathrm{MPa} / \mathrm{km}$ and 23 $\mathrm{MPa} / \mathrm{km}$ in the belt and foredeep, respectively, in agreement with the values inferred in the northern Apennine belt and in the Po Plain by Montone and Mariucci [2015]. Moving from the Apennine area to the Adriatic coast, we observe a difference of $\sim 15$ MPa of lithostatic pressure, for instance at a depth of $5 \mathrm{~km}$ (Fig. 4). This can imply that toward the foredeep, because the extensional tectonic regime is confined to the axial belt, even though the SHmax gradient was still the same (within the range of the Sv gradi- ents relative to the Apennines and the foredeep), the relative magnitude of the principal stress axes would change into a strike-slip or compressive tectonic regime. Unfortunately no data are available in this sector of the belt to estimate the Shmin magnitude, while further analysis could be performed in the foredeep area.

Very interesting is the comparison among the three different stress indicators available in this area: active fault measurements at surface, breakout data at intermediate depth and $\mathrm{T}$-axes from earthquake focal mechanisms in the deep crust. Earthquake focal mechanisms and breakouts are in good agreement also with the coseismic ruptures mapped for more than $5.2 \mathrm{~km}$ along the Mt. Vettore Fault System characterized by $\mathrm{N} 160^{\circ}$-striking normal faults, SW-dipping [EMERGEO, 2016], revealing a homogeneous stress field orientations for the entire crust along the depth.

Quaternary faults [e.g. Galadini et al., 2001] together with the breakouts, the previous seismic sequences and the past seismicity indicate a small rotation of Shmin orientation. In fact, from $\sim \mathrm{NE}$, in the southernmost part, for instance in the area of the 2009 L'Aquila seismic sequence, Shmin changes to $\sim$ ENE in the northern sector (1979 Norcia earthquakes), up to the wells and the 2016 Amatrice sequence area. The previous hypothesis [Mariucci et al., 2010] based only on deep well data has been confirmed: in this area occurs a slight rotation of horizontal stress axes with respect to the northern and southern sectors. The new focal mechanisms define the picture suggested in the past by only two boreholes enhancing the role of breakouts as reliable stress indicators in those areas where other information are few. 


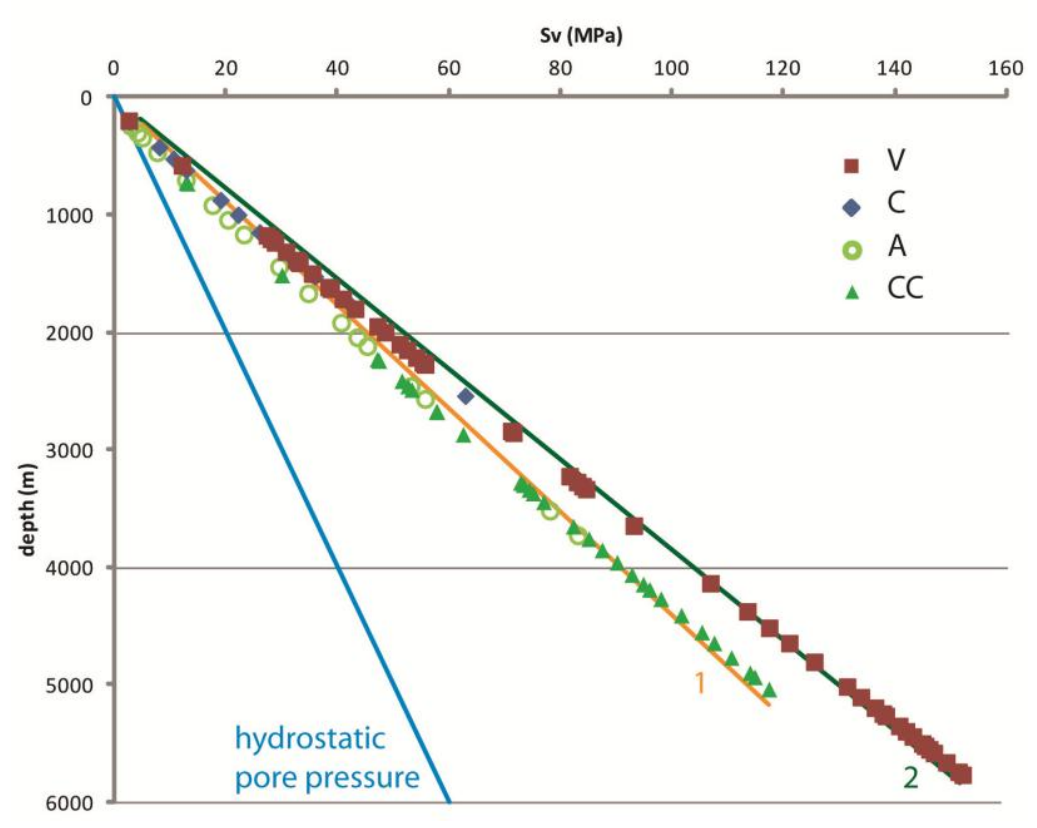

Figure 4. Vertical stress (Sv) estimated from sonic log data. 1, trend line of data from the wells in the foredeep ( $A$ and $C C) ; 2$, is relative to the wells in the Apennine belt ( $V$ and $C)$.

\section{REFERENCES}

BSI, Bollettino Sismico Italiano gruppo di lavoro Amatrice (2016). Rapporto preliminare sulle attività svolte dal gruppo Bollettino Sismico Italiano a seguito del terremoto di Amatrice Mw 6.0 (24 agosto 2016, Italia centrale). doi: 10.5281 / zenodo.157545.

Cornet, F.H. and Rockel, T. (2012). Vertical stress profiles and the significance of "stress decoupling". Tectonophysics, 581:193-205, doi:10.1016/j.tecto.2012.01.020.

EMERGEO W.G. (2016). Coseismic effects of the 2016 Amatrice seismic sequence: first geological results. Annals of Geophysics, 59, Fast Track 5, DOI: 10.4401/ag-7195.

Federico, C. and Pauselli, C. (1998). Thermal evolution of the Northern Apennines (Italy).
Mem. Soc. Geol. It., 52:267-274.

Frepoli, A. and Amato, A. (1997). Contemporaneous extension and compression in the northern Apennines from earthquake faultplane solutions. Geophys. J. Int., 129:368-388. Galadini, F., Meletti, C. and Vittori, E. (2001). Major active faults in Italy: available surficial data, Geologie en Mijnbouw-Netherlands / Journal of Geosciences, 80(3-4):273-296. Gardner, G.H.F., Gardner L.W. and Gregory, A.R. (1974). Formation velocity and density The diagnostic basics for stratigraphic traps. Geophysics, 39:770-780.

Heidbach, O., Tingay, M., Barth, A., Reinecker, J., Kurfeß, D. and Muiller, B. (2010). Global crustal stress pattern based on the World Stress Map database release 2008. Tectonophysics, 482:3-15. do- 
i:10.1016/j.tecto.2009.07.023.

Lavecchia, G., Brozzetti, F., Barchi, M., Menichetti, M. and Keller, J.V.A. (1994). Seismotectonic zoning in east-central Italy deduced from an analysis of the Neogene to present deformations and related stress fields. Geological Society of American Bulletin, 106:1107-1120.

Mariucci, M.T., Montone, P. and Pierdominici, S. (2010). Present-day stress in the surroundings of 2009 L'Aquila seismic sequence (Italy), Geophysical Journal International, 182(2): 1096-1102, doi: 10.1111/j.1365-246X.2010.04679.x.

McKenzie, D.P. (1969). The relation between fault plane solutions for earthquakes and the directions of the principal stress. Bull. seism. Soc. Am., 59:591-601.

Montone, P. and Mariucci, M.T. (2015). Pwave velocity, density, and vertical stress magnitude along the crustal Po plain (Northern Italy) from sonic log drilling data. Pure Appl. Geophys., 172:1547-1561, doi:10.1007/s00024-014-1022-5.

Montone, P. and Mariucci, M.T. (2016). The new release of the Italian contemporary stress map. Geophysical Journal International, 205:1525-1531, doi: 10.1093/gji/ggw100.

Montone, P., Mariucci, M.T. and Pierdominici, S. (2012). The Italian presentday stress map. Geophys. J. Int., 189:705-716, doi:10.1111/j.1365-246X.2012.05391.x.

Pauselli, C., Ranalli, G. and Federico, C. (2010). Rheology of the Northern Apennines: Lateral variations of lithospheric strength. Tectonophysics, 484(1-4):27-35, doi:10.1016/j.tecto.2009.08.029.

Pondrelli, S., Salimbeni, S., Ekström, G., Morelli, A., Gasperini, P. and Vannucci, G. (2006). The Italian CMT dataset from 1977 to the present. Phys. Earth Planet. Int., 159(34):286-303, doi:10.1016/j.pepi.2006.07.008.
Roselli, P. and Mariucci, M.T. (2016). Preliminary remarks on the earthquake focal mechanism forecasts applied in the Amatrice sequence (Central Italy). Submitted to Annals of Geophysics, this issue.

Scognamiglio L., Tinti E. and Quintiliani, M. (2016). The 2016 Amatrice seismic sequence: fast determination of time domain moment tensors and finite fault model analysis of the ML 5.4 aftershock. Submitted to Annals of Geophysics, this issue.

Zoback, M.L. (1992). First- and second-order patterns of stress in the lithosphere: the world stress map project. J. geophys. Res., 97(B8):703-728. 